Anna Wylegała

\title{
Ukraińskie dyskusje o Holokauście: wokół książki Omera Bartova
}

Krótko po opublikowaniu anglojęzycznej wersji książki Omera Bartova Erased: Vanishing Traces of Jewish Galicia in Present-Day Ukraine (Princeton: Princeton University Press, 2007) na ukraińskim portalu dyskusyjnym www.zgroup.com.ua (Zachodnia Grupa Analityczna) ukazała się recenzja, której autor prorokował Bartovowi rolę ukraińskiego Jana Tomasza Grossa. „O ile mi wiadomo, składanie na UPA odpowiedzialności za ludobójstwo ludności żydowskiej w Galicji pozbawione było do tej pory dostatecznego uzasadnienia. [...] Ponieważ teraz za sprawę tę wziął się doświadczony specjalista, całkiem prawdopodobne jest, że galicyjscy Ukraińcy dostaną swoje Jedwabne"1. Ihor Czornowoł po wielokroć przecenił potencjał książki Bartova, w jednym jednak miał rację: na dłuższy czas zdominowała ona ukraińskie dyskusje o Zagładzie.

Dlaczego właśnie ta publikacja, a nie jakaś inna? Powodów można by wymienić kilka. Na pierwszy plan wysuwa się z pewnością radykalizm i kontrowersyjność tez postawionych przez Bartova. Ważną rolę odgrywa jednak również to, że jest to publikacja przeznaczona dla szerokiej publiczności, nie zaś czysto akademicka monografia. Koniec końców - nie bez znaczenia jest mała liczba książek o tej tematyce, wydawanych na Ukrainie. Bartov nie miał zbyt dużej konkurencji. Zacznijmy jednak od początku. Książka Bartova, amerykańsko-izraelskiego historyka zajmującego się do tej pory przede wszystkim wojenną historią Niemiec nazistowskich ${ }^{2}$, ma formę notatek z podróży. Autor relacjonuje w niej swoje wrażenia z wyprawy po Galicji, w której trakcie zbierał materiały do monografii poświęconej historii wieloetnicznego Buczacza. Rzecz przypomina z pozoru luźny przewodnik po dwudziestu galicyjskich miastach i miasteczkach, które zamieszkane były kiedyś w większości lub w dużej części przez ludność żydowską (historia społeczności żydowskiej do drugiej wojny światowej, Zagłada, dziedzictwo materialne i miejsca pamięci współcześnie), ale autor dodał do tego aparat naukowy: przypisy i bibliografię. Najważniejsze

\footnotetext{
${ }^{1}$ Ihor Czornowoł, Prinstonśkyj palimpsest, 15 IV 2008, http://www.zgroup.com.ua/article.php?articleid=440, dostęp 12 IV $2011 \mathrm{r}$.

${ }^{2}$ Zob. Omer Bartov, Mirrors of Destruction: War, Genocide, and Modern Identity, New York: Oxford University Press, 2000; idem, Hitler's Army: Soldiers, Nazis, and War in the Third Reich, New York: Oxford University Press, 1991.
} 
tezy książki można by streścić w trzech zdaniach. Po pierwsze, Ukraińcy - przede wszystkim partyzanci Ukraińskiej Powstańczej Armii, policja pomocnicza, ale także tzw. zwykli ludzie - przez czynną współpracę z niemieckim okupantem współodpowiedzialni są za Holokaust. Po drugie, po fizycznym unicestwieniu społeczności żydowskiej w Galicji rozpoczęło się po wojnie i trwa nieprzerwanie niszczenie śladów spuścizny materialnej tej społeczności. Po trzecie, w polityce historycznej współczesnej Ukrainy nie ma miejsca na pamięć o Zagładzie, upamiętnia się za to i heroizuje jej sprawców - nacjonalistów ukraińskich.

Jak łatwo się domyślić, książka wywołała pewne poruszenie w ukraińskim świecie naukowym. Dyskutowano o niej na długo przed pojawieniem się ukraińskiego przekładu, choćby na konferencji naukowej „Dziedzictwo i historia Żydów w miastach Europy Środkowo-Wschodniej”, zorganizowanej przez Centrum Historii Miejskiej Europy Środkowo-Wschodniej we Lwowie (Bartov był jednym z prelegentów) ${ }^{3}$. Jedna z pierwszych i bodaj najważniejsza recenzja wyszła spod pióra Jarosława Hrycaka, wybitnego lwowskiego historyka średniego pokolenia, zajmującego się między innymi ukraińską tożsamością narodową. Hrycak rozpoczął swój tekst od stwierdzenia, że książki naukowe można podzielić na cztery kategorie: dobrze napisane dobre książki, źle napisane dobre książki, dobrze napisane złe książki i źle napisane złe książki. „Mam problem z ostatnią książką Omera Bartova - nie wiem, do której grupy ją zaliczyć. Oczywiste jest, że nie do pierwszej. I prawdopodobnie nie do ostatniej. Zaliczyłbym ją do grupy drugiej, gdyby nie... No właśnie, wokół tego "gdyby» chciałbym zbudować moją recenzję"4. „Gdyby” Hrycaka okazało się w istocie miażdżącą krytyką książki Bartova. Lwowski historyk wypunktował metodycznie liczne pomyłki faktograficzne książki, wybiórcze podejście do źródeł, nieznajomość kontekstu (Bartov nie zna ukraińskiego, w pracy nad książką korzystał z tłumaczeń i źródeł w innych językach, jest to jego „pierwsze podejście” do historii regionu). Nie polemizował z głównymi tezami Bartova, lecz podjął bardzo udaną próbę wyjaśnienia przyczyn tego, co Bartov jedynie zdiagnozował, nie starając się zrozumieć; najważniejszą podnoszoną przez niego kwestią była sowietyzacja ukraińskiej pamięci historycznej, której skutków autor Erased zupełnie nie wziął pod uwagę.

Recenzja Hrycaka zapoczątkowała dyskusję, której punktem kulminacyjnym było „Forum książkowe”, zamieszczone w prestiżowym kijowskim kwartalniku historycznym „Ukrajina moderna”. Znalazło się w nim pięć obszernych recenzji oraz odpowiedź samego Bartova. Książkę recenzowało dwóch naukowców z Niemiec (Anna Weronika Wendland i Kristian Ganzer), jeden z Ukrainy (Tarik Cyril Amar), Kanady (Myrosław Szkandrij) oraz z Rosji (Ilia Gierasimow). Opinie recenzentów

\footnotetext{
${ }^{3}$ Szczegółowa relacja z konferencji, również w języku polskim, dostępna jest na stronie internetowej Centrum: http://www.lvivcenter.org/pl/conferences/jewishheritage/, dostęp 19 IX $2011 \mathrm{r}$.

${ }^{4}$ Zob. Jarosław Hrycak, Hołokost poprostu, „Ji” 2009, nr 58, http://www.ji.lviv.ua/ n58texts/hrycak.htm, dostęp 19 IX $2011 \mathrm{r}$.
} 
były dość spolaryzowane: od pełnych aprobaty i jednoznacznie podkreślających wagę książki Bartova dla pozytywnych przemian w ukraińskiej pamięci historycznej, do miażdżąco krytycznych, a przy tym niezwykle emocjonalnych. Wymowę zdecydowanie najbardziej pozytywną miał obszerny tekst Amara, ówcześnie dyrektora lwowskiego Centrum Historii Miejskiej i osoby bardzo zaangażowanej w galicyjskie życie akademickie i intelektualne. Jego rozbudowana recenzja jest jednocześnie ostrą diagnozą: to, co dzieje się obecnie na Ukrainie w dziedzinie polityki pamięci, jest bardzo niepokojące, ponieważ świadomie przekłamuje się część historii. Pisanie o współudziale powstańców w Holokauście nie sprzyja heroizacji ukraińskiego ruchu narodowego, tę część historii UPA konsekwentnie się więc przemilcza. Amar poruszył także inne trudne kwestie, takie jak przejmowanie przez Ukraińców mienia pożydowskiego. Tak bezlitośnie wyliczone przez Hrycaka niedociągnięcia metodologiczne i faktograficzne uznał za mało istotne, ripostując, że apologeci UPA popełniają nie mniejsze pomyłki. Równie bezkompromisowo podszedł do problemu drugi z recenzentów, Ilia Gierasimow (redaktor naczelny kazańskiego pisma „Ab Imperio”, zajmującego się problemami nacjonalizmu na obszarze postradzieckim), który swój tekst zatytułował Pamięć judenrein. Podobnie jak Amar, recenzję potraktował jako pretekst do gorzkich rozważań nad kondycją postsowieckiej (bo nie tylko ukraińskiej!) tożsamości narodowej, piętnując bezkrytyczny kult ruchów narodowowyzwoleńczych, kreowanie konkurencyjnych martyrologii i fałszywą poprawność polityczną wobec tzw. narodów tytularnych (czyli w tym wypadku Ukraińców). Swój tekst zakończył ironicznym pytaniem o to, czy Ukraińcy wolą być traktowani zgodnie z ogólnoeuropejskim standardami, a więc w sposób wymagający, czy też zadowala ich postkolonialne podejście, w którym oczekuje się od nich w dziedzinie rozliczeń z przeszłością mniej niż od Niemców lub Francuzów. Jego wywód jest w sposób pośredni polemiką z recenzją Anny Weroniki Wendland, która stwierdziła, że Ukraina potrzebuje na uporanie się ze swoją przeszłością tyle czasu ile inne kraje, na przykład Niemcy i Austria na rozliczenie z nazizmem czy Stany Zjednoczone na uznanie swojej winy wobec Indian i Afroamerykanów. Idąc w ślady Hrycaka, Wendland zwróciła też uwagę na pomijany zupełnie przez Bartova kontekst traumatyzacji i sowietyzacji pamięci i tożsamości ukraińskiej. Jej zdaniem o współczesnej Ukrainie w każdym z jej przejawów nie da się pisać uczciwie, nie mając w pamięci głośnej książki Orlando Figesa o „społeczeństwie szeptaczy”, które do dzisiaj pozostaje żywe w wielu mieszkańcach dawnego Związku Radzieckiego. Krytykę w podobnym duchu przeprowadził Kristian Ganzer, który zarzucił Bartovowi uprzedzenia wobec obserwowanej rzeczywistości i niedbałość w opisie faktów historycznych, co podważa jego wiarygodność jako historyka i dowodzi lekceważącego stosunku do Ukraińców (na przykład opatrywanie zbiorczą nazwą „nacjonaliści ukraińscy" grup o różnym rodowodzie i poglądach). Na biegunie przeciwległym do entuzjastycznej recenzji Amara oraz wyważonej krytyki pozostałych osób znajduje się tekst Myrosława Szkandrija, kanadyjskiego literaturoznawcy pochodzenia ukraińskiego. Szkandrij w emocjonalnym tonie zarzucił Bartovowi elementarny brak szacunku wobec ukraińskich dążeń niepodległościowych i prawa 
Ukraińców do czczenia swoich bohaterów, a także niedostrzeganie pozytywnych aspektów relacji ukraińsko-żydowskich, również tych z okresu wojny. Miał mu ponadto za złe krzywdzące generalizacje w odniesieniu do działalności formacji powstańczych. Stwierdził też, że do zrozumienia sytuacji na ziemiach ukraińskich podczas drugiej wojny światowej konieczne jest mówienie o wszystkich popełnianych tam zbrodniach, w tym o zbrodniach komunistów (wśród których, jak pisze, było wielu Żydów), nie zaś tylko o samej Zagładzie.

Nie będę się tu zajmować obszerną odpowiedzią Bartova, który zręcznie (choć moim zdaniem nie zawsze przekonująco) odparł zarzuty wszystkich swoich oponentów. Chciałabym natomiast skomentować krótko przebieg dyskusji, która pokazuje ukraińskie dyskusje o Zagładzie w pigułce. Znaczące jest to, że żaden z recenzentów nie podważał głównych tez Bartova, tj. ukraińskiej współodpowiedzialności za Holokaust czy nieobecności Zagłady w ukraińskiej polityce pamięci. Nikt też nie polemizował z diagnozą o katastrofalnym stanie żydowskiego dziedzictwa materialnego na Ukrainie - w obliczu przytłaczającej rzeczywistości byłoby to zresztą niepoważne; wszyscy zaś jednogłośnie zgadzali się co do tego, że ogólnie jest to książka ważna i potrzebna. Pozycję zarówno krytyków, jak i apologetów Bartova pod tym względem streszcza niejako fragment przedmowy do przekładu książki pióra jej ukraińskiego wydawcy, dyrektora Ukraińskiego Centrum Studiów nad Holokaustem, Anatolija Podolśkiego: „Książka amerykańskiego historyka Omera Bartova, publikowana obecnie w języku ukraińskim, może przyczynić się do ważnego zjawiska, a mianowicie, do podjęcia czy też do bardziej gruntownego prowadzenia otwartej dyskusji w społeczeństwie ukraińskim na temat koncepcji pamięci historycznej, w której nie będziemy po raz kolejny budować jednej tylko linii historii, czy to heroicznej, czy to martyrologicznej, lecz spróbujemy powiedzieć, że byliśmy uczestnikami historii jako takiej"5.

Przy zgodzie co do potrzeby otwartej dyskusji i transformacji ukraińskiej pamięci w taki sposób, by znalazło się w niej miejsce dla licznych spychanych obecnie na dalszy plan „Innych” i „Obcych”, w niektórych kwestiach książka Bartova budzi jednak na Ukrainie (oraz wśród naukowców z zagranicy zajmujących się problematyką regionu) niepokój i pewien sprzeciw. Chodzi tu przede wszystkim o rażące uproszczenia i generalizacje, których dopuszcza się autor; nie tylko podważają one wiarygodność faktograficzną publikacji, lecz także zasadność niektórych interpretacji. Kluczowym zarzutem, podnoszonym przez kilku recenzentów, jest przecenianie przez Bartova znaczenia zachodnioukraińskiego nacjonalizmu spod znaku OUN-UPA; jak twierdzi między innymi Hrycak, gdyby to przede wszystkim jego przedstawiciele odpowiadali za katastrofalny stan spuścizny żydowskiej i symboliczną nieobecność Zagłady w dyskursie publicznym, sytuacja w innych regionach Ukrainy byłaby lepsza. Tymczasem również na Ukrainie Centralnej i Wschodniej,

${ }^{5}$ Anatolij Podolśkyj, Znechtuwanyj epizod istroiji... Peredmowa do perszoho ukrajinśkoho wydannia [w:] Omer Bartow, Sterti. Znykajuczi slidy jewrejiw Hałyczyny w suczasnij Ukrajini, tłum. S. Kołomyjec, Kyjiw: Ukrajinśkyj Centr Wywczennia Istoriji Hołokostu, 2010, s. 13. 
„nieskażonych” w najmniejszych stopniu galicyjskim nacjonalizmem, ukraińska pamięć historyczna jest, używając sformułowania Gierasimowa, tak samo „judenrein”. Kolejna kwestia to wybiórczość w doborze źródeł i w oglądzie współczesności: zdaniem wielu krytyków Bartov widzi w historii tylko negatywne aspekty relacji ukraińsko-żydowskich, a we współczesności nie dostrzega inicjatyw społecznych podejmowanych dla ratowania i upamiętnienia dziedzictwa żydowskiego na Ukrainie. Pewne tezy Bartova budzą też wątpliwości lub wskazują na rozterki intelektualistów ukraińskich. Czy ktokolwiek poza samymi Ukraińcami ma prawo „wymagać” od nich rozliczenia z przeszłością? Które podejście naznaczone jest większym paternalizmem i postkolonializmem - to, które ze względu na ciężar totalitarnej traumy stosuje wobec Ukrainy taryfę ulgową w rozliczaniu się z przeszłością, czy to, które nie liczy się z lokalną specyfiką i nie próbuje spojrzeć na ukraińskie postawy wobec Zagłady w kontekście całej historii ukraińskiej? Co jest ważniejsze dla budowania współczesnej tożsamości ukraińskiej: wykreowanie pozytywnego bohatera zbiorowego w postaci nieskalanej UPA, a więc zgoda na kolektywne zapomnienie o pewnych faktach, czy otwarte, a przy tym bardzo bolesne rozliczenie się z przeszłością? Do którego momentu atrofię pamięci usprawiedliwiać można sowiecką spuścizną?

Po zapoznaniu się z problemami podejmowanymi w ukraińskich dyskusjach „wokół Bartova” polski czytelnik zastanawia się zapewne, dlaczego nie stał się on „ukraińskim Grossem”. Wydaje mi się, że zaważyło na tym kilka kwestii. Po pierwsze, o ile książki obu autorów przeznaczone były w ich zamyśle dla szerokiego kręgu czytelników, o tyle Erased pozostało pozycją znaną raczej w świecie akademickim. W Polsce zarówno wydanie Sąsiadów, jak i Strachu czy Złotych żniw było szeroko komentowane w różnych mediach - prasie codziennej, radiu, telewizji, a kontrowersje wokół tez Grossa stały się pretekstem do otwartej debaty o stosunkach polsko-żydowskich w czasie okupacji i po wojnie. Na Ukrainie dyskusja była bardzo ożywiona i nie mniej (lub nawet bardziej) merytoryczna, ograniczała się jednak do wąskich i dość elitarnych środowisk intelektualnych. O Bartovie pisano, ale nie w prasie będącej odpowiednikiem „Gazety Wyborczej” czy „Rzeczpospolitej”, lecz w czasopismach branżowych, takich jak „Ukrajina moderna”, czy czytywanym głównie przez liberalną, „prozachodnią” inteligencję miesięczniku „Krytyka”, w którym po prezentacji ukraińskiego przekładu w październiku 2010 r. ukazała się krótka notka o książce. Dyskutowano, ale nie w telewizji i nie na forach internetowych, lecz na skierowanych raczej do profesjonalistów konferencjach i seminariach - wystarczy powiedzieć, że poza historykami zajmującymi się tematem na spotkaniu promującym wydanie ukraińskiego tłumaczenia Erased zjawiło się kilkanaście osób. Wydaje mi się więc, że z uwagi na większą hermetyczność ukraińskiego dyskursu akademickiego (mniejszą siłę oddziaływania ukraińskich intelektualistów?) Bartov nie wywołał dotychczas na Ukrainie tak masowej debaty o stosunkach ukraińsko-żydowskich, jak Gross w Polsce. Drugą kwestią różniącą dyskusję ukraińską od polskiej jest jej regionalizm. Każda pamięć zbiorowa jest złożona i mieści w sobie różne doświadczenia historyczne, czasami wzajemnie sprzeczne. Niemniej 
zbiorowa pamięć narodowa Ukraińców jest o wiele bardziej podzielona niż pamięć Polaków. Nie ma tu miejsca na streszczanie sporu o istnienie dwóch czy dwudziestu dwóch Ukrain ${ }^{6}$, ale trzeba zauważyć, że kwestie palące i bolesne w Galicji moga nie budzić żadnych emocji na Ukrainie Wschodniej lub - co jeszcze bardziej komplikuje sprawę - budzić emocje zupełnie przeciwstawne. Książka Bartova uderzyła w czuły punkt zachodnioukraińskiej tożsamości, na Wschodzie zaś przeszła zupełnie niezauważona; być może oprócz pamięci wernakularnej podzielona jest na Ukrainie również przestrzeń wymiany intelektualnej.

Grossa od Bartova różni jeszcze jedna ważna kwestia. Książki Grossa powstały, ponieważ ich autor wierzył, że polska pamięć narodowa potrzebuje terapii wstrząsowej; niewątpliwie przyjął założenie, że terapia ta ma duże szanse się powieść. Bartov wydaje się nie mieć zbyt wielkiej nadziei w stosunku do społeczeństwa ukraińskiego. Jak pisze: „Ta książka nie została napisana po to, by czytać ją z przyjemnością. Jej przedmiotem jest znikanie materialnych pozostałości oraz pamięci o żydowskim życiu w Ukrainie Zachodniej, znanej w przeszłości jako Galicja Wschodnia [...]. Obawiam się jednak, że znikanie to, zachodzące na równi z winy sił przyrody i człowieka, postępuje szybciej niż jakakolwiek lokalna inicjatywa czy dobre zamiary przeciwdziałania tej degradacji. Być może publikacja tej książki w języku ukraińskim odegra swoją niewielką rolę w zachowaniu tego, co jeszcze można zachować, i wzmocni powolny proces badania i ochrony w pamięci tego, co przez długi czas było spowite milczeniem i zapomnieniem”. Co znamienne, pesymizm Bartova podzielają też niektórzy recenzenci jego książki - choć ma on zupełnie inne podstawy. W swojej recenzji w kijowskiej „Krytyce” Wadym Dywnycz wprost napisał, że odbudowa pamięci o Żydach ukraińskich jest niewątpliwie sprawą ważną, ale bynajmniej nie najważniejszą obecnie na Ukrainie: „Omer Bartov zarzuca społeczeństwu ukraińskiemu niechęć i obojętność wobec pamięci o Żydach jako ważnym składniku historii ukraińskiej. W kraju, którego spora część mieszkańców chciałaby pozbyć się z niego właśnie Ukraińców, zajmowanie się uczuciami mniejszości narodowych staje się w oczach zagrożonej «większości», zmuszonej do troszczenia się o własne przetrwanie, bardzo odległą w czasie potrzebą, a jej zaspokojenie odkładane jest na bliżej nieokreśloną przyszłość”. Nie da się ukryć, że głosy takie potwierdzają tylko pesymistyczne prognozy Bartova.

Mimo wszystkich swoich ograniczeń książka Bartova, a zwłaszcza publikacja jej ukraińskiego tłumaczenia, była wydarzeniem bardzo ważnym dla ukraińskich rozrachunków z przeszłością, nie tylko tych dotyczących stosunków ukraińsko-

${ }^{6}$ Zainteresowanych tematem odsyłam do klasycznej polemiki Jarosława Hrycaka z Mykołą Riabczukiem: Mykoła Riabczuk, Dwie Ukrainy, tłum. Marta Dyhas i in., Wrocław: Kolegium Europy Wschodniej, 2004; Jarosław Hrycak, Dwadciat’ dwi Ukrajiny [w:] idem, Strasti za nacjonalizmom. Istoryczni ese, Kyjiw: Krytyka, 2004.

${ }^{7}$ Omer Bartow, Peredmowa do ukrajinśkoho wydania [w:] idem, Sterti. Znykajuczi slidy jewrejiw Hatyczyny..., s. 15-22.

${ }^{8}$ Wadym Dywnycz, Omer Bartov, „Sterti. Znykajuczi slidy jewrejiw Hałyczyny w suczasnij Ukrajini”, „Krytyka” 2010, nr 9-10. 
-żydowskich. Pośrednio każda dyskusja o pamięci Zagłady i dziedzictwa żydowskiego jest też dyskusją ogólną o ukraińskiej tożsamości i włączeniem bądź wyłączeniem z niej Innych - Polaków, Niemców, Tatarów, Czechów, czasami również Rosjan. Anatolij Podolśkyj, ukraiński wydawca książki, zamieścił w swoim wstępie do przekładu następujący komentarz: „Moim zdaniem chodzi o uznanie (lub nieuznanie) przez Ukrainę, społeczeństwo, państwo własnej historii i kultury za zróżnicowaną, polietniczną - ze wszystkimi pozytywnymi i negatywnymi aspektami stosunków etnicznych i kulturowych, które stąd wynikają. Albo na przykład o zgodę na monoetniczny model pamięci o przeszłości historycznej swojego kraju, który automatycznie wyklucza wspólną pamięć różnych wspólnot etnicznych, przez stulecia mieszkających na tej samej ziemi”".

Pozostaje tylko mieć nadzieję, że pesymistyczne prognozy Bartova i części jego krytyków na temat dalszego rozwoju dyskusji okażą się chybione.

${ }^{9}$ Podolśkyj, Znechtuwanyj epizod istroiji..., s. 11. 